\title{
Afrikaanse taalvariasie: Uitdagings vir regverdige meting van jong kinders se taal ${ }^{1}$
}

\author{
Frenette Southwood \\ Departement Algemene Taalwetenskap, Universiteit Stellenbosch, Suid-Afrika \\ E-mail: $\underline{\text { fs@sun.ac.za }}$
}

\section{Helena Oosthuizen}

Afdeling Spraak-, Taal- en Gehoorterapie, Universiteit Stellenbosch, Suid-Afrika

E-mail: oosthe@sun.ac.za

\section{Opsomming}

Sowat 5\% van alle kinders toon 'n taalagterstand (Law, Boyle, Harris, Harkness en Nye 2000) en daar is aanduidings dat hierdie syfer hoër is in Suid-Afrika, veral onder baie jong kinders (Van der Linde, Swanepoel, Sommerville, Glascoe, Vinck en Louw 2016). Geen voldoende instrument bestaan waarmee vasgestel kan word watter jong Afrikaanssprekendes hulp sal benodig om toekomstige taalverwante akademiese probleme te oorkom nie. Hierdie artikel lewer verslag oor uitdagings wat weens Afrikaanse taalvariasie ervaar word tydens die ontwikkeling van 'n ouervraelys waarmee jong kinders se taal gemeet kan word. Hierdie vraelys beslaan vrae oor vroeg-ontwikkelende kommunikatiewe gebare, eerste woorde en vroeë sinskonstruksies, en ouers word versoek om op die lys aan te dui watter gebare, woorde en konstruksies hul kind verstaan en/of voortbring. Die vraelys kan nie onbeperk verleng word nie, want die voltooiing daarvan moet 'n realistiese taak bly, ook vir ouers met lae geletterdheidsvlakke (vgl. Alcock, Rimba, Holding, Kitsao-Wekulo, Abubakar en Newton 2015). Besluite oor die insluiting of uitsluiting op die vraelys van woorde uit spesifieke Afrikaanse variëteite is egter gereeld nie voor die hand liggend nie.

Bestaande taalmetingsinstrumente diskrimineer wêreldwyd tipies teen kinders wat nie deel van die dominante kultuur en taalgemeenskap vorm nie. Gegee Suid-Afrika se bevlekte geskiedenis wat die erkenning van sprekers van niegestandaardiseerde taalvariëteite betref (vgl. bv. Hendricks 2012; Williams 2016), is die opstel van 'n geldige ouervraelys ononderhandelbaar. Daar moet dus noukeurig oorweeg word watter woorde op die lys verskyn, want 'n goeie ouervraelys sal bydra tot kultureel- en talig-regverdige taaltoetsing van jong Afrikaanssprekende kinders. Dit sal help om kinders te identifiseer wat sukkel om hul taal te

\footnotetext{
${ }^{1}$ Heather Brookes (Universiteit van Kaapstad) en Mabutšana Ramokoatsi (Universiteit Stellenbosch) vir Sesotho, Michelle Pascoe en Olebeng Mahura (Universiteit van Kaapstad) vir Setswana, Sefela Yalala and Martin Mössmer (Universiteit van Kaapstad) vir isiXhosa, Mikateko Ndhambi (Sefako Makgatho Gesondheidswetenskappe Universiteit) vir Xitsonga, Michelle White (Universiteit van Kaapstad en Universiteit Stellenbosch) en Naledi Kgolo en Rose Letsholo (Universiteit van Botswana).
} 
verwerf en wat ekstra hulp benodig sodat hul taal genoegsaam kan verbeter vóór hul formele skoolloopbaan begin. Sodoende sal hulle 'n groter kans hê om die kurrikulum te verstaan, skoolsukses te ervaar en'n lang genoeg skoolloopbaan te hê om hul potensiaal te verwesenlik.

Kernwoorde: Afrikaans, ouervraelys, kindertaalverwerwing, taalvariëteit, CDI

\begin{abstract}
Approximately $5 \%$ of children show a language delay (Law, Boyle, Harris, Harkness and Nye 2000), and there are indications that this figure is higher in South Africa, especially amongst very young children (Van der Linde, Swanepoel, Sommerville, Glascoe, Vinck and Louw 2016). There are no adequate instruments with which to ascertain which young Afrikaansspeaking children will require assistance to overcome future language-related academic problems. This article reports on the challenges experienced owing to Afrikaans language variation during the development of a parent questionnaire with which the language acquisition of young children can be measured. This questionnaire comprises questions on early developing communicative gestures, first words, and early grammatical constructions, and parents are requested to indicate on the list which gestures, words and constructions their child comprehends and/or produces. The length of the questionnaire needs to be contained, because the completion of the questionnaire should remain a realistic task for parents, also for those with low literacy levels. Decisions regarding the inclusion or exclusion on the questionnaire of the words found in specific varieties of Afrikaans are however often not straightforward.
\end{abstract}

Existing language assessment instruments the world over typically discriminate against children who are not part of the dominant culture and language community. Given South Africa's stained history with regard to the recognition of speakers of non-standardised language varieties (cf., e.g., Hendricks 2012; Williams 2016), the compiling of a valid parental questionnaire is non-negotiable. It is thus necessary to consider carefully which words should appear on the list, because a good parental questionnaire can contribute to culturally and linguistically fair language assessment of young Afrikaans-speaking children. Such a questionnaire will assist in identifying children who struggle to acquire their language and who need extra assistance in order for their language to improve sufficiently before the commencement of their school careers. That way, they will have a better chance of accessing the curriculum, of experiencing academic success, and of having a sufficiently long school career to realise their potential.

Keywords: Afrikaans, parent questionnaire, child language acquisition, language variety, CDI

\title{
1. Inleiding
}

Die doel van die artikel is om verslag te lewer oor die uitdagings wat 'n mens in die gesig staar tydens die ontwikkeling van 'n ouervraelys waarmee jong Afrikaanssprekende kinders (8 tot 30 maande) se taalverwerwing gemeet en gemonitor kan word. Ons fokus in hierdie artikel nie op logistieke uitdagings (soos dié wat te make het met befondsing, die oplei van veldwerkers en koste-effektiewe steekproefneming) nie, maar op daardie uitdagings wat met Afrikaanse taalvariasie te make het. Ter agtergrond verduidelik ons waarom 'n mens kinders se taal sou wou meet (in Afdeling 2), hoe 'n mens tans Afrikaanssprekende kinders se taal kan meet (in Afdeling 3) en watter tipe woorde ingesluit behoort te word in 'n taalmetingsinstrument vir 
gebruik met jong Afrikaanssprekendes (in Afdeling 4). Daarna bespreek ons die uitdagings wat ons ervaar (in Afdeling 5). Die artikel word afgesluit met opmerkings oor navorsing oor kindertaalverwerwing onder Afrikaanssprekende kinders en watter bydrae dit kan lewer buiten dat dit van waarde vir die kinders self kan wees.

\section{Redes waarom 'n mens kinders se taal sou wou meet}

Die Verenigde Nasies se Volhoubare Ontwikkelingsdoelwitte sluit die beëindiging van armoede, die bevordering van goeie gesondheid en welsyn, en die versekering van inklusiewe en hoë-gehalte opvoeding in (United Nations 2018). Vir kinders met taalagterstande is hoëgehalte opvoeding gewoonlik nie 'n moontlikheid nie, want die waarskynlikheid is klein dat hulle ten volle baat sal vind by hoofstroom-onderwys. Redes hiervoor sluit in dat hierdie kinders probleme ervaar om dít wat hulle in die klas hoor en dít wat hulle in handboeke en leesboeke lees te prosesseer (Catts, Fey, Tomblin en Zhang 2002; McCormack, McLeod, McAllister en Harrison 2009; Stoeckel, Colligan, Barbaresi, Weaver, Killian en Katusic 2013). Hulle sukkel ook gereeld om hulself duidelik en noukeurig in gesproke en geskrewe vorme uit te druk (Preston, Frost, Mencl, Fulbright, Landi, Grigorenko, Jacobsen en Pugh 2010; Tomblin, Zhang, Buckwalter en Catts 2003). Kinders met taalagterstande en/of taalgestremdheid ${ }^{2}$ loop dan die risiko van 'n onbevredigende beroepslewe, want hulle word as minder aanstelbaar beskou omdat hulle swak gevaar het op skool of hul skoolloopbaan voortydig beëindig het (ContiRamsden, Durkin, Mok, Toseeb en Botting 2016; McCormack et al. 2009).

Volgens die studie van Broomfield en Dodd (2004) het 5,6\% van baie jong kinders ( 0 tot 2 jaar) in die Verenigde Koninkryk 'n spraak- en taalgestremdheid, en dit stem ooreen met die mediaan van 5\% wat vir ander lande gerappoteer is in 'n sistematiese oorsig van die literatuur uitgevoer deur Law, Boyle, Harris, Harkness en Nye (2000). Daar is aanduidings dat hierdie syfer hoër is in Suid-Afrika (vgl. Van der Linde, Swanepoel, Sommerville, Glascoe, Vinck en Louw 2016 wat bevind het dat $13 \%$ van die 6- tot 12-maand oue kinders - en ongeveer ewe veel meisies en seuns - in hul studie 'n taalagterstand toon). Die rede hiervoor is die meer algemene voorkoms van risikofaktore vir taalagterstand in ontwikkelende lande. Hierdie faktore sluit in egskeiding of gesinskeiding (Beitchman, Jiang, Koyama, Johnson, Escobar, Atkinson, Brownlie en Vida 2008); armoede, geweld, HIV-infeksie en middelafhanklikheid (Samuels, Slemming en Balton 2012); lae opvoedingsvlakke onder ouers (Harrison en McLeod 2010) en beperkte ouer-kind-interaksie (Barwick, Cohen en Horodezky 2004). Taalagterstand is een van die mees algemene vorme van ontwikkelingsagterstande, en verwysing van kinders na professionele persone weens 'n vermoedelike taalagterstand is 'n algemene aanduiding van

\footnotetext{
2 In hierdie artikel verwys "taalagterstand" na 'n agterstand in die ontwikkeling van taal as geheel, wat tipies 'n kleiner as verwagte woordeskat vir die kind se chronologiese ouderdom insluit asook taalstruktuur wat ooreenstem met dié van jonger kinders. Die agterstand kan in die ekspressiewe domein voorkom (in welke geval die kind se probleem by die produksie van taal lê) of in beide die reseptiewe en ekspressiewe domein (in welke geval die kind ook met die begip van taal probleme ervaar). "Taalgestremdheid" het verskeie sinonieme (insluitend "spesifieke taalgestremdheid", "taalafwyking" en "ontwikkelingstaalafwyking") en verwys na taal wat atipies is in die sin dat dit nie die taalsisteem van jonger tipies-ontwikkelende kinders weerspieël nie. Volgens Rice, Warren en Betz (2005) is die tipe foute wat kinders met taalgestremdheid maak onversoenbaar met wat bekend is oor enige gegewe vlak van tipiese taalontwikkeling. 'n Taalgestremdheid sluit egter tipies 'n taalagterstand in; kinders met taalgestremdheid toon 'n agterstand in terme van die produksie van eerste woorde en eerste woordkombinasies dit wil sê, hierdie woorde en kombinasies word later as ouderdomsverwagting geproduseer (Trauner, Wulfeck, Tallal en Hesselink 1995).
} 
gehoor-gestremdheid en ontwikkelingsagterstande soos intellektuele agterstande ${ }^{3}$ of taalgestremdheid. ${ }^{4}$

Ouers is dikwels die eerstes wat 'n taalagterstand in hul kinders bespeur (vgl. Rannard, Lyons en Glenn 2005; ook Johnson en Myers 2007 vir ouers van kinders met outisme), maar sonder instrumente waarmee daar vasgestel kan word of 'n kind se taal werklik te stadig ontwikkel vir sy/haar ouderdom, kan 'n mens nie bepaal watter kinders hulp benodig nie. Goeie inligting oor die wyse waarop tipies-ontwikkelende kinders taal verwerf en waarop hulle taalgewys in hul gesinne en kulturele konteks gesosialiseer word, word benodig alvorens die nodige hulp verleen kan word aan daardie kinders wat 'n risiko loop om 'n taalagterstand te ontwikkel.

Teen hierdie agtergrond is die eerste rede waarom 'n mens kinders se taal sou wou meet om te probeer vasstel watter kinders gespesialiseerde hulp benodig. As daar vroeg in die kind se lewe goeie inligting oor sy/haar taalverwerwing beskikbaar is, stel dit ' $\mathrm{n}$ mens in staat om opvoedkundige en ander dienste vroeg en beter te beplan (vgl. bv. Robertson en Ellis Weismer 1999) sodat die negatiewe impak van taalagterstand of taalgestremdheid op die kind se akademiese sukses sover moontlik beperk kan word (vgl. Young, Beitchman, Johnson, Douglas, Atkinson, Escobar en Wilson 2002). Daar is verskeie moontlike redes waarom 'n bepaalde kind se taal stadiger as ander kinders van sy/haar ouderdom ontwikkel. Sommige kinders ontgroei sonder hulp hul taalagterstand, maar waar die agterstand weens onvoldoende taalinsette en gebrekkige talige sosialisering in lae sosio-ekonomiese kontekste (vgl. Perkins, Finegood en Swain 2013), gehoorgestremdheid, taalgestremdheid, of sommige ander ontwikkelingsafwykings blyk te wees, is intervensie tipies nodig om die taalagterstand aan te spreek, en die voordele van vroeë taalintervensie (eerder as intervensie wat eers later in die kind se lewe 'n aanvang neem) is welbekend (vgl. bv. Ward 1999).

' $n$ Tweede rede is dat ' $n$ mens kinders se taalverwerwing oor tyd moet kan monitor. Dit is nie noodsaaklik vir alle kinders nie, maar dit is wel nuttig om so te kan maak vir bepaalde groepe kinders. Sommige navorsers of pediaters mag byvoorbeeld wil vasstel of (en indien wel, hoe) ARV-behandeling van swanger en borsvoedende MIV-geïnfekteerde vroue hul kinders se ontwikkeling (d.i. motoriese, kognitiewe, emosionele maar ook talige ontwikkeling) beïnvloed tydens die voorskoolse en laerskooljare (vgl. Alcock, Ali, Newton en Holding 2016; Hattam, Louw en Geertsema 2014). Ander navorsers mag wil vasstel of 'n sekere intervensieprogram wel taalverwerwing onder kinders bevorder (vgl. Dickinson, Griffith, Golinkoff en Hirsh-Pasek 2012 vir 'n boeklees-intervensie).

'n Derde rede waarom 'n mens kinders se taal wil meet, en wil vasstel hoe hulle taal in sosiale kontekste verwerf, is omdat navorsing oor taalverwerwing bydra tot die ryk kulturele grondslag van 'n taalgemeenskap. Taalwetenskap en die studie van kindertaal kan 'n bydrae lewer tot 'n streek se kulturele erfenis, veral in gevalle waar die tersaaklike kultuurgroep vantevore afgeskeep is in terme van navorsingsaandag.

\footnotetext{
${ }^{3}$ Marrus en Hall (2017) noem dat die teenwoordigheid van 'n taalagterstand behoort te lei tot verdere ondersoeke met die kind, juis sodat 'n intellektuele agterstand nie misgekyk word nie.

4 Taalgestremdheid is 'n risikofaktor vir 'n klein woordeskat, minstens vanaf 5 -jarige ouderdom tot in volwassenheid (Beitchman et al. 2008) en dus vir 'n taalagterstand in minstens die woordeskatdomein.
} 


\section{Wyses waarop die taal van jong Afrikaanssprekende kinders tans gemeet kan word}

Alhoewel daar reeds navorsing oor Afrikaanssprekende kinders se taalverwerwing gedoen is (vgl. bv. Brink en Breed 2017; Buitendag, Uys en Louw 1998; Nel 2015; Southwood, Carinus en Engelbrecht 2010; Van der Merwe 2008), het hierdie navorsing nog nie gelei tot die ontwikkeling van taaltoetse wat gefokusde talige hulp vir kinders met Afrikaans as moedertaal moontlik maak nie (vgl. Pascoe en Smouse 2012). Sulke hulp is wel nodig, want (soos hierbo verduidelik) taalagterstande kan kinders se akademiese vordering kniehalter. Taalagterstande kan ook kinders se vatbaarheid vir skaamheid en lae selfbeeld verhoog (Jerome, Fujiki, Brinton en James 2002; Wadman, Durkin en Conti-Ramsden 2008), en hulle die teikens van boelies maak (Egan en Perry 1998; vgl. ook Yew en O’Kearney 2013).

Tans is daar geen talige, kulturele of andersins geldige en betroubare instrument waarmee die taal van jong Afrikaanssprekende kinders gemeet en gemonitor kan word nie. Daar bestaan wel siftingsinstrumente wat gebruik kan word om vas te stel of 'n kind se taal tipies ontwikkel en of daar 'n moontlikheid van taalagterstand bestaan. Een hiervan is die Ages and Stages-vraelys (Squires en Bricker 2009) wat gebruik kan word vir kinders wat 4 maande tot 5 jaar oud is. Hierdie siftingsvraelys dek 'n wye reeks ontwikkelingsareas: Buiten kommunikasieontwikkeling word daar ook vrae gevra oor groot- en fynmotoriese ontwikkeling, probleemoplossing, en persoonlike en sosiale ontwikkeling. Oor elke ontwikkelingsarea word daar aan die ouer ses vrae gestel. Die ouer moet aandui of die kind 'n sekere vaardigheid ken/vertoon deur Ja, Soms of Nog nie te selekteer. Hierdie antwoorde word dan bepunt om 'n telling te bereken wat bepaal of die kind in die slaag-kategorie of risiko-kategorie val. Die vraelys is in Afrikaans vertaal en as meetinstrument met 'n groep Afrikaanssprekende kinders gebruik (vgl. Visser, Nel, Bronkhorst, Brown, Ezendam, Mackenzie, Van der Merwe and Venter 2016). Terwyl so 'n siftingstoets handig is, lewer dit nie aan die navorser of spraak-taalterapeut diepgaande inligting oor die aard van die kind se talige kennis nie.

Die Language Development Survey (Rescorla 1989) is ontwerp om 'n vroeë taalagterstand onder kinders van 18 tot 35 maande te identifiseer. Die vraelys beslaan 309 woorde wat in 14 semantiese kategorieë gerangskik is, en ouers dui aan watter van daardie woorde die kind reeds spontaan produseer. 'n Aangepaste Engelse weergawe (waarin 22 van die Amerikaanse Engelse woorde met Suid-Afrikaanse ekwivalente vervang is) is met sukses gebruik deur Gonasillan, Bornman en Harty (2013) om data in te samel onder Engelssprekende kinders in Suid-Afrika sowel as tweetalige kinders wat Engels as taal het naas Afrikaans, Sepedi, Sesotho, Setswana of isiZulu. Daar is egter nie 'n Afrikaanse weergawe beskikbaar nie, en slegs ekspressiewe taalvaardighede word geassesseer. Die vraelys is ook nie geskik vir gebruik met kinders jonger as 18 maande nie. In 'n opname onder Suid-Afrikaanse spraak-taalterapeute (Van Dulm en Southwood 2013) het geen van die deelnemende 158 spraak-taalterapeute met Afrikaanssprekende kinders in hul gevallelading aangedui dat hulle die Language Development Survey gebruik om die taalvaardighede van hierdie kinders te assesseer nie.

Bornman, Romski, Tonsing, Sevcik, White en Barton-Hulsey (2018) het die Mullen Scales of Early Learning (Mullen 1995) in Afrikaans, Setswana en isiZulu vertaal en dit ook kultureel aangepas vir Suid-Afrikaanse Engels. Die skale vorm 'n battery waarmee jong kinders (0 tot 68 maande) se ontwikkeling van groot- en fynmotoriese vaardighede, visuele waarneming (waarna ook verwys word as "nie-verbale probleemoplossing"), taalbegrip en taalproduksie 
gemeet kan word. Elke skaal behels interaktiewe take wat deur die kind voltooi word en dan bepunt word deur die waarnemer. Daar mag ook 'n onderhoud met die ouer gevoer word om te help met die bepunting. Die skale beslaan in totaal 124 items waarvan 33 taalbegrip en 28 taalproduksie teiken. In die studie van Bornman et al. (2018) waarin die vertaalde en aangepaste Afrikaanse weergawe beproef is, is slegs kinders van 21 maande en ouer ingesluit, en daar is dus nie inligting beskikbaar oor hoe heelwat jonger Afrikaanssprekende kinders vaar nie.

Die Rossetti Infant-Toddler Language Scale (Rossetti 1990) is 'n instrument wat in sommige lande wyd gebruik word om die ontwikkeling van taal en interpersoonlike interaksie van kinders van 0 tot 36 maande te ondersoek. Dit fokus onder meer op reseptiewe en ekspressiewe taalvaardighede. Die instrument word ook in Suid-Afrika wyd gebruik in navorsing (vgl. bv. Groenewald, Kritzinger en Viviers 2013), maar nie in die praktyk met spesifiek Afrikaanssprekende kinders nie; in die opname van Van Dulm en Southwood (2013) het slegs vyf van die 158 spraak-taalterapeute aangedui dat hulle die Rossetti Infant-Toddler Language Scale met Afrikaanssprekende kinderkliënte gebruik.

Die ontwikkeling van 'n instrument waarmee Afrikaanssprekende kinders se taal op 'n omvattende wyse gemeet kan word, is onderweg (gebaseer op die Diagnostic Evaluation of Language Variation; Seymour, Roeper en De Villiers 2005), maar sal slegs vir gebruik met 4tot 9-jariges geskik wees. 'n Teorie-gebaseerde instrument bestaan wel reeds (die Afrikaanse weergawe van die LITMUS MAIN; Klop, Visser en Oosthuizen 2011; vgl. ook Gagarina, Klop, Kunnari, Tantele, Välimaa, Balčiūnienė, Bohnacker en Walters 2012), maar maak gebruik van storievertel en -oorvertel en is daarom slegs vir ouer Afrikaanssprekende kinders geskik. Dit is wel belangrik om skooltipe taalvaardighede in ouer Afrikaanssprekende kinders te meet sodat die kinders hulp kan verkry met daardie vaardighede wat hulle kortkom en wat hulle nodig het om sinvol met die skoolkurrikulum om te gaan (Nippold 2016). Dit is egter ook belangrik om jong kinders (jonger as 4 jaar) se taalvaardighede te meet sodat vroeë ingryping gereël kan word om sodoende die kinders se kanse te verbeter om maats van hul ouderdom in terme van taalvaardighede in te haal en hul skoolloopbaan suksesvol te voltooi. Op een na moet taaltoetse vir sulke jong Afrikaanssprekendes egter nog ontwikkel word.

Direkte toetsing van kinders van hierdie jong ouderdom kan onaangenaam vir die kind wees, veral in kontekste van armoede waar kinders min ervaring van formele onderrig of doelgerigte opvoedkundige interaksie met volwassenes het. Dit kan ook lei tot veranderde gedrag in die kind wat weer kan lei tot 'n onderskatting van die kind se taalvermoëns (Fenson, Dale, Reznick, Bates, Thal, Pethick, Tomasello, Mervis en Stiles 1994). Ouers weet die meeste oor hul kinders se ontwikkeling en kan akkuraat oordeel wat hul kinders weet en nie weet nie (Fenson et al. 1994). Ouers kan goed verslag lewer oor hul kinders se huidige vermoëns (ouers se geheue oor wat hul kinders in die verlede kon doen of nie kon doen nie, is egter soms vaag) en kan vaardighede beter herken as wat hulle vaardighede onthou (uitkengeheue is dus beter as herroepingsgeheue; vgl. Dale, Bates, Reznick en Morisset 1989; Duke 2017). Daar is al in verskeie geografiese en sosio-ekonomiese kontekste oor die wêreld heen met sukses vir ouers gevra om hul kinders se huidige taalvaardighede uit te ken (eerder as om die vaardighede sonder leidrade te herroep); vergelyk byvoorbeeld Fenson, Marchman, Thal, Dale, Reznick en Bates (2007) vir die Verenigde State van Amerika; Hamadani, Baker-Henningham, Tofail, Mehrin, Huda en Grantham-McGregor (2010) vir Bangladesj; Simonsen, Kristoffersen, Bleses, Wehberg en Jørgensen (2014) vir Noorweë; Alcock et al. (2015) vir Kenia. Wat hiervoor benodig word, is 'n omvattende lys woorde, frases en kort sinne wat vroeg ontwikkel in 
kindersprekers van die tersaaklike taal, in hierdie geval Afrikaans. Alhoewel daar vir meer as 68 tale (onder andere sewe wat in die sub-Sahara-streek gepraat word) sulke lyste bestaan (vgl. Dale en Penfold 2011), is daar nog nie so 'n lys vir Afrikaans of enige ander amptelike SuidAfrikaanse taal nie.

Terwyl taaltoetse geskik kan wees vir gebruik met ouer Afrikaanssprekende kinders, is die gebruik van 'n ouervraelys gewens as 'n mens inligting oor die taalverwerwing van jong kinders wil verkry. Nie net kan ouers inligting verskaf oor die ware toedrag van sake (wat aan andere onbekend sal wees) nie, maar ouerverslaglewering is ook koste- en tydseffektief. Soos hierbo genoem, is daar egter nie tans 'n geskikte Afrikaanse ouervraelys beskikbaar vir gebruik met baie jong kinders nie. Daar bestaan natuurlik vraelyste wat oorsee in sogenaamde WOIRDkontekste ontwikkel is (Westers, geOnderrig, geÏndustrialiseerd, Ryk en Demokraties; vgl. Henrich, Heine en Norenzayan 2010), maar hulle kan nie sonder meer vertaal word in Afrikaans nie, want die soorte woorde, frases en sinne wat kinders ontwikkel, is hoogs afhanklik van die konteks waarin die kinders hulself bevind (Hoff 2003). Daar moet dus 'n ouervraelys vir Afrikaans ontwikkel word om te verseker dat die inhoud daarvan kontekstueel tersaaklik en talig en kultureel toepaslik is.

\section{Vroeg-ontwikkelende woorde in die taal van Afrikaanssprekende kinders}

Die presiese woorde wat die vroegste deur 'n kind verwerf word, hang van die kind se kulturele, sosio-ekonomiese, geografiese en ander kontekste af. Kinders wat Amerikaanse Engels verwerf, produseer byvoorbeeld cracker as een van hulle eerste 50 woorde (Caselli, Bates, Casadio, Fenson, Fenson, Sander en Weir 1995), terwyl dit onwaarskynlik is dat Engelssprekende Suid-Afrikaanse kinders hierdie woord vroeg sal verwerf; soortgelyk is die ekwivalent van horlosie onder die eerste 50 woorde van Italiaanssprekende kinders in Sentraalen Noord-Italië (Caselli et al. 1995), terwyl dit onwaarskynlik is dat dit 'n vroeg-ontwikkelende woord onder kinders in ontwikkelende lande sal wees. Daar is twee datastelle beskikbaar oor baie jong Afrikaanssprekendes se taal. Dié van Van Dulm (geen datum) is slegs in 'n mate relevant hier, want die jongste ouderdom wat in hierdie databasis ingesluit is, is 18 maande en data is van slegs twee kinders (in dieselfde dorp) versamel. Die datastel verskaf wel waardevolle inligting, maar kan nie as verteenwoordigend van die taalverwerwing van Afrikaanssprekende babas en peuters beskou word nie. Die tweede datastel is dié van Brink (2018) wat saamgestel is uit ouers se dagboekinskrywings oor vroeë leksikale items van hul kinders. Data is oor 21 Afrikaanssprekende kinders beskikbaar en is vir elke kind oor 'n tydperk van 5 maande versamel. Die jongste kind was 6 maande ten tye van die aanvang van data-insameling en die oudste kind was 23 maande toe data-insameling voltooi is. Brink en Breed (2017) se studie handel oor hoe hierdie kinders betekenis aan hul vroegste leskikale items verbind. In teenstelling met Afrikaans (en Suid-Afrikaanse tale oor die algemeen) is daar internasionaal reeds heelwat navorsing gedoen oor watter woorde vroeg verskyn, en die volgende bespreking steun op dié internasionale navorsing, met verwysing na die datastel van Brink (2018) waar toepaslik.

Die heel vroegste stadia van taalverwerwing word oorheers deur die produksie van leksikale items wat moeilik is om in terme van grammatikale klas te klassifiseer, byvoorbeeld byklanketikette (soos dieregeluide, bv. moo op 15 maande in Brink 2018), name vir persone wat belangrik in die kind se versorging is (bv. dadda vir pappa op 7 maande in Brink 2018) en roetine-etikette (soos groetwoorde - bv. tatta op 9 maande in Brink 2018 - of die ekwivalent 
van $o p$ wat met uitgestrekte arms gepaardgaan; vgl. Caselli et al. 1995; Brink 2018 vir op op 14 maande). Vir Engelssprekende kinders in die studie van Caselli et al. (1995) was die eerste 10 woorde wat geproduseer is die ekwivalent van baai (die informele vorm van totsiens), bal, bottel, haai (die informele vorm van hallo), hond, mamma, mê, nee, $\hat{o}-\hat{o}$ (wat gewoonlik geuiter word as iets val, breek of andersins skeefloop) en pappa. Vir Italiaanssprekendes het die ekwivalente van die volgende 10 woorde eerste verskyn: broem-broem, doedoe, mamma, nannas ('n woord wat na enige kos of na etenstyd as geheel verwys), nee, ouma, oupa, pappa, water en woef-woef (vgl. ook Vihman en Kunnari 2006 vir eerste woorde in Engels, Fins, Frans en Wallies). Baie van hierdie woorde kom ook in die datastel van Brink (2018) voor: mamma, nee, pappa en ouma op 7 maande, tatta en nanna op 9 maande, hallo en oupa op 10 maande, woef (om na 'n hond te verwys) op 11 maande, bal op 12 maande, doedoe op 12 tot 16 maande, am-am (vir broem-broem) op 13 maande en water op 17 of 18 maande. Die hoë proporsie moeilik klassifiseerbare woorde neem egter af na gelang die kind se woordeskat vergroot. Dit het daartoe gelei dat Caselli et al. (1995:183) beweer dat eiename en byklanke die "afskoppers" vir nominale uitdrukkings in kindertaal is en roetine-etikette die "afskoppers" vir nie-nominale, soos werkwoorde.

Babas blyk vroeg reeds te kan onderskei tussen oopklaswoorde (of inhoudswoorde, wat naamwoorde, byvoeglike naamwoorde en werkwoorde insluit) en gesloteklaswoorde (of funksiewoorde, wat lidwoorde, kwantifiseerders en voorsetsels insluit) (Gomez 2002; Morgan, Shi en Allopenna 1996). Teen die ouderdom van 9 tot 10 maande verkies kinders om na oopklaswoorde te luister; Waxman en Lidz (2006) stel voor dat dit die geval is omdat oopklaswoorde meer beklemtoon word deur sprekers en meer interessante melodiese kontoere as gesloteklaswoorde het.

Uit die oopklaswoorde blyk naamwoorde vroeër en vinniger te ontwikkel as werkwoorde en ander grammatikale klasse; vergelyk Haman, Łuniewska, Hansen, Simonsen, Chiat, Bjekić, Blažienè, Chyl, Dabašinskienè, Engel de Abreu, Gagarina, Gavarró, Håkansson, Harel, Holm, Kapalková, Kunnari, Levorato, Lindgren, Mieszkowska, Montes Salarich, Potgieter, Ribu, Ringblom, Rinker, Roch, Slančová, Southwood, Tedeschi, Müge Tuncer, Ünal-Logacev, Vuksanović en Armon-Lotem (2017) vir hierdie bevinding in 13 tale, naamlik Britse Engels, Duits, Fins, Hebreeus, Italiaans, Katalaans, Litous, Luxemburgies, Pools, Serbies, Slowaaks, Suid-Afrikaanse Engels en Turks (vgl. ook Bornstein, Cote, Maital, Painter, Park, Pascual, Pecheux, Ruel, Venuti en Vyt 2004 vir 'n kruislinguistiese oorsig en Brink 2018 vir Afrikaans soos hieronder bespreek). Party navorsers beweer dat hierdie naamwoord-voorrang wel betrekking mag hê op leksikale verwerwing van Engelssprekende kinders maar dat dit nie vir alle tale geld nie (vgl. bv. Gopnik, Choi en Baumberger 1996 vir Koreaans, en Tardif, Gelman en Xu 1999 vir Mandaryns). Ander navorsers, wat op die proporsionele frekwensie van die voorkoms van naamwoorde en werkwoorde in ouerberigte kindertaal gefokus het, het egter bevind dat kindertaalverwerwers van verskeie tale naas Engels (insluitende tale wat tipologies van Engels verskil, soos Hebreeus, Japannees en Turks) wel hierdie naamwoord-voorrang toon (vgl. bv. Fernald en Morikawa 1993). Hierdie tale het ook Koreaans ingesluit, al kom baie meer werkwoorde as naamwoorde in opvallende sinsposisies voor in die taal wat Koreaanssprekende volwassenes aan babas rig (in teenstelling met Engels, waarin meer naamwoorde as werkwoorde in opvallende sinsposisies voorkom; vgl. Au, Dapretto en Song 1994).

Eerste naamwoorde (dié wat onder die eerste 50 woorde verskyn) in die taal van Amerikaanse Engelssprekende kinders is (in volgorde van frekwensie van voorkoms) die ekwivalente van 
mamma, pappa, bal, hond en bottel (soos hierbo genoem) asook baba, katjie, boek, voël, eend, ballon, kat, skoen, piesang, sap, oog, ouma, koekie, neus, soutbeskuitjie, oupa, bad, sleutels, borrels, kar, kaas, beer, vis en hoed (Caselli et al. 1995). Die ooreenstemmende Italiaanse lys lyk soos volg: mamma, pappa, ouma, water en oupa (soos hierbo genoem) asook bal, skoene, kind, brood, koekie, hond, fopspeen, oom, melk, horlosie, tannie, piesang, pop en kat (Caselli et al. 1995). Dit val op dat sommige naamwoorde in beide Engels en Italiaans onder die eerste 50 woorde verskyn (bal, hond, kat, koekie, mamma, ouma, oupa, pappa, piesang en skoen/e), maar dat ander woorde slegs in Engels (baba, bad, ballon, beer, boek, borrels, bottel, eend, hoed, kaas, kar, katjie, neus, oog, voël, sap, sleutels, soutbeskuitjie en vis) of slegs in Italiaans (brood, fopspeen, horlosie, kind, melk, oom, pop, tannie en water) vroeg verskyn. Alhoewel Brink (2018) nie noodwendig haar deelnemers se eerste woorde vasgevang het nie, het sy wel vroeë woorde in haar datastel, en Afrikaanse naamwoorde (eiename ingesluit) beslaan sowat $61 \%$ van woorde in hierdie datastel. ${ }^{5,6}$

In terme van eerste werkwoorde was daar in die studie van Caselli et al. (1995) geen werkwoorde onder die eerste 50 woorde vir die Engelssprekende kinders nie, en slegs een vir die Italiaanssprekende kinders (naamlik die ekwivalent van gee), en hierdie werkwoord is deur slegs 10\% van die Italiaanssprekende kinders gebruik. Onder die volgende 50 woorde wat deur die Engelssprekende kinders verwerf is (dit wil sê, die eerste 100 woorde), was daar wel werkwoorde, naamlik die ekwivalente van gaan, sien, eet en byt. Vir Italiaans was daar in die tweede stel van 50 woorde wat kinders verwerf vier addisionele werkwoorde, naamlik die ekwivalente van huil, wieg, eet en oopmaak. Werkwoorde beslaan sowat $13 \%$ van die Afrikaanse datastel van Brink (2018). ${ }^{7}$

Byvoeglike naamwoorde en funksiewoorde is ook raar onder die eerste 100 woorde wat kinders verwerf, en byvoeglike naamwoorde blyk láter as naamwoorde te verskyn (Caselli et al. 1995). Volgens Waxman en Lidz (2006) is dit teen die verwagting in, want daar is 'n hoë voorkoms van byvoeglike naamwoorde in die taal wat van vroeg af aan babas gerig word. Tog is daar baie min byvoeglike naamwoorde in kinders van 8 tot 16 maande se woordeskat: 2,5\% van die totale woordeskat van Engelssprekendes het uit byvoeglike naamwoorde bestaan (die ekwivalent van

\footnotetext{
${ }^{5}$ Die berekeninge aangaande die woorde in die datastel van Brink (2018) is telkens gemaak deur elke tipe woord (in teenstelling met elke token) te tel en volgens woordsoort te klassifiseer. Die woord bal (met 'n benaderde of volwasse uitspraakvorm) is byvoorbeeld in total 31 maal deur 13 van die 21 kinders geuiter, maar is slegs een maal getel toe die aantal woorde in die naamwoord-kategorie bereken is. Verkleinwoorde is nie bygereken nie, tensy die woord nie ook in die nie-verkleinde vorm in die datastel voorgekom het nie. Bok en bokkie is dus as een woord getel, en tjippie is as 'n woord getel (want tjip is nie deur enige kind in die datastel gebruik nie).

${ }^{6}$ Hierdie naamwoorde $(\mathrm{n}=149)$ is aarbei, aartappel, akkedis, akker, alarm, apie, appel, arms, avo, baadjie, baba, bad, bak, bakkie (waaruit 'n mens kan eet), bakkie (die voertuig), bal, bed, beer, bees, bene, blaar, blom, boek, boetie, bok(kie), boom, bril, broek, brood, buffel, bus, Bybel, doedoe, doek, druiwe, drukkie, duim, "dummy”, eend(jie), eier, emmer, ertjies, fietsie, geldjie, gordyne, gras, gorilla, hadeda, hare, hasie, hek, helikopter, hemp, hoed, huis, jakkals, jogurt, "juice”, kaas, kar (vir stootwaentjie), kat, kiewiet, klere, knoop/knopie, koekie, koedoe, koeldrink, koeskoes, kossies, kouse, lemoen, lepel, lieweheersbesie, lig, maag, maan, maatjie, man, masker, melk, mes, mielie, mier, mond, mop, mot, muis, muur, naeltjie, nek, noedels, ö̈, oom, oorbelle, padda, pap(pies), papaja, papegaai, papier, pasta, perdjie, pen, prop, rasper, reën, sak, sjampoe, sjokolade, skapie, skoen, skool, sleutel, stoel, stok, sussie, tafel, takbok, tande, tannie, tas, teddie, tee, tent, tiek-tok, tier, tietie, tietiebottel, tissue, tjippie, toilet, tone, tong, trekker, trok, trui, tuin, universiteit, varkie, vissie, vlieg, vliegtuig, voël, voete, waaier, water, werk (soos in Pappa is by die werk), wortel, ys en ysie. Daar is 49 eiename in die datastel, wat die name van familielede, versorgers, maats en troeteldiere insluit.

${ }^{7}$ Hierdie werkwoorde ( $\mathrm{n}=42$, wat twee hulpwerkwoorde insluit) is aantrek, bad, bars, bêre, blaai, blaas, bou, byt, doedoe, draai, haal, hap, help, hoor, huil, inklim, kam, kom, kuier, kyk, loop, moenie, mors, nies, piepie, proe, sal, sit, skop, skryf, sny, speel, spring, stamp, stappies, stort, swaai, swem, uitlos, uittel, was en wegkruip.
} 
warm en oppella was die enigste twee onder die kinders se eerste 50 gesproke woorde) en $0,5 \%$ van Italiaanssprekendes se woordeskat het uit byvoeglike naamwoorde bestaan, met nie een byvoeglike naamwoord wat onder die eerste 50 woorde voorgekom het nie (Caselli et al. 1995). In die Brink (2018)-datastel was 9,5\% van die woorde byvoeglike naamwoorde, ${ }^{8}$ en $1,8 \%$ van die woorde is as bywoorde geklassifiseer. ${ }^{9}$

Wat betref funksiewoorde, wat ook laat verskyn, was daar in die studie van Caselli et al. (1995) twee (die ekwivalente van op en $a f$ ) onder Engelssprekendes se eerste 50 woorde en een onder Italiaanssprekendes (die ekwivalent van myne). Funksiewoorde het in totaal 4,4\% van die woordeskat van 8- tot 16-maand-oue Engelssprekendes beslaan en 1,4\% van die woordeskat van Italiaanssprekendes van dieselfde ouderdom. Funksiewoorde se frekwensie van voorkoms in die datastel van Brink $(2018)^{10}(4,0 \%)$ stem ooreen met dié van die Caselli et al. (1995) se Engelssprekendes.

Daar blyk dus ooreenstemming tussen tale te wees in terme van die soorte woorde wat kinders eerste verwerf. Daar is egter variasie tussen tale in terme van die tempo waarin kinders woorde verwerf. De Boysson-Bardies en Vihman (1991) het byvoorbeeld bevind dat Japanneessprekende kinders hul eerste 25 woorde stadiger verwerf as Engels-, Frans- en Sweedssprekendes, waarskynlik om redes wat te make het met die kenmerke van individuele woorde in Japannees. Bornstein et al. (2004) het ook verskille in die tempo van woordeskatverwerwing gevind tussen sommige van die sewe tale wat hulle bestudeer het (Engels, Frans, Hebreeus, Italiaans, Koreaans, Nederlands en Spaans): Koreaanssprekende kinders het die kleinste en Russiessprekende kinders die grootste woordeskat getoon op ouderdom 20 maande. Bleses, Vach, Slott, Wehberg, Thomsen, Madsen en Basbøll (2008) het 14 tale bestudeer (en in totaal data oor meer as 26000 kinders ingesamel) en bevind dat Deense kinders in die ouderdomsband 8 tot 30 maande minder woorde ken as kinders wat enige van die ander 13 tale verwerf, vermoedelik weens die spesifieke fonologiese eienskappe van Deens wat Deense woorde minder fonologies deursigtig en moeiliker waarneembaar maak.

Daar is ook variasie onder kinders wat dieselfde taal verwerf. Vergelyk byvoorbeeld Fenson et al. (1994) se studie van 1803 tipies-ontwikkelende Engelssprekende Amerikaanse kinders van 8 tot 30 maande: Sommige ouers van 16-maand-oue kinders het berig dat hul kind nog nie 'n enkele woord kon sê nie terwyl ander berig het dat hul kind meer as 100 woorde kon sê. Ook uit die datastel van Brink (2018) blyk interkind-variasie duidelik, beide in terme van die hoeveelheid woorde wat die ouers in die 5-maand periode opgeteken het en in terme van die spesifieke woorde wat die verskillende kinders ken. Koedoe is byvoorbeeld in 'n relevante konteks deur 'n meisie van 16 maande geproduseer, kiewie( $t$ ) deur 'n seun van 20 maande en ma (masker, vir stofmasker) deur 'n meisie van 20 maande. Hierdie drie woorde is nie deur enige van die ander 18 kinders in die datastel geproduseer nie.

\footnotetext{
${ }^{8}$ Die byvoeglike naamwoorde ( $\left.\mathrm{n}=31\right)$ is baie, blou, dors, drie, eina (of seer), gebreek, groen, "gross", hard, hier, klaar, klein, koud, leeg, lekker, moeg, mooi, nat, nog, oop, oulik, pers, pienk, rooi, stout, swart, tien, toe (as teenoorgestelde van oop; die voorsetsel toe kom ook voor), twee, warm (of soe-soe) en weg.

${ }^{9}$ Die bywoorde $(\mathrm{n}=6)$ is buite, daar, hier, hierso, lekker en self (in Ek self loop).

${ }^{10}$ Hierdie funksiewoorde ( $\left.\mathrm{n}=13\right)$ is aan, af, almal, binne, daai, dit, ene, myne, op, s'n, toe (soos in toilet toe), waar en wat.
} 
Opsommend is daar, ten spyte van variasie in woordeskat-ontwikkelingstempo oor tale en kinders heen, wel ooreenstemmende patrone in die soorte woorde wat eerste verwerf word. Die eerste woorde wat kinders sê, het gewoonlik te make met belangrike mense in hul lewe (bv. mamma, pappa, ouma, oupa), roetines (bv. hallo, tatta), kos (bv. nanna, melk, piesang) en diere (bv. hond, kat) (vgl. Tardif, Fletcher, Liang, Zhang, Kaciroti en Marchman 2008). 'n Mens verwag dus dat naamwoorde vóór werkwoorde, byvoeglike naamwoorde en funksiewoorde in Afrikaanssprekende kinders se woordeskat sal ontwikkel en ook dat die presiese woorde wat vroeg verwerf word, tot 'n mate onder Afrikaanssprekende kinders sal verskil na gelang van die omstandighede waarin die kind grootword. Die taak is nou om vas te stel wat die waarskynlike eerste woorde is wat Afrikaanssprekendes ontwikkel sodat 'n ouervraelys vir Afrikaans ontwikkel kan word, en dit is die taak waarmee ons tans besig is.

\section{Uitdagings tydens die ontwikkeling van 'n lys vroeg-ontwikkelende Afrikaanse woorde}

Voordat ons die uitdagings bespreek, gee ons ter kontekstualisering kortliks inligting oor die protokol wat ons volg om die ouervraelys op te stel. Die ontwikkeling van die Afrikaanse ouervraelys vorm deel van die Suider-Afrikaanse Communicative Developmental Inventories (CDI)-projek waarin navorsers aan vyf universiteite ooreenstemmende ouervraelyste vir sewe Suider-Afrikaanse tale ontwikkel deur dieselfde navorsingsprotokol te volg (Afrikaans, isiXhosa, Sesotho, Setswana, Siswati, Suid-Afrikaanse Engels en Xitsonga; vgl. Dowling en Whitelaw 2018; Pascoe, Mahura, Brookes, Dowling, Oosthuizen, Southwood, Kgolo, Letsholo en Alcock 2018). Ons vertrekpunt was die vertaling in Afrikaans van 'n lys vroegontwikkelende Amerikaanse Engelse woorde, naamlik die MacArthur-Bates Communicative Development Inventory (Fenson, Dale, Reznick, Thal, Bates, Hartung, Pethick en Reilly 1993), want dit blyk die vertrekpunt te wees van vele navorsingspanne wat soortgelyke ouervraelyste vir ander tale in ander wêrelddele ontwikkel het. Hierdie Amerikaanse lys het twee weergawes, een vir babas ( 8 tot 18 maande) en een vir peuters (16 tot 30 maande). Die baba-lys bevat naas woorde ook kommunikatiewe en ander gebare, en die peuterlys bevat naas woorde ook frases en kort sinne. Vir die doel van hierdie artikel neem ons egter slegs die woorde in ag. Soos in die geval van die Amerikaanse weergawe wil ons hê ouers moet aandui of hul kinders 'n bepaalde gebaar of kort sin gebruik al dan nie, watter woorde die kinders slegs verstaan en watter woorde hulle verstaan en ook al kan sê. Ná vertaling is ons lys voorgelê aan Afrikaanssprekende taalwetenskaplikes en spraak-taalterapeute in verskillende geografiese gebiede (die Wes-Kaap, die Noord-Kaap en Gauteng) om onmiddellike terugvoer te ontvang oor woorde wat weggelaat moet word omdat hulle beslis onvanpas sou wees vir ' $n$ vraelys oor die woorde wat 8- tot 30-maand-oue Afrikaanssprekende kinders ken (soos eland "moose" en sneeupak "snow suit"). Hierdie rondte van raadpleging is opgevolg deur twee fokusgroepbesprekings, met die samestelling van die groepe wat uiteenlopend was in terme van geografiese ligging, sosio-ekonomiese status, taalvariëteit, etnisiteit en beroep van die deelnemers, wat almal Afrikaanssprekend was. Een fokusgroep het in 'n staatsgesondheiddienssentrum in Upington ontmoet en het bestaan uit 'n apteker, die pa van 'n 2-jarige seun; 'n verpleegster uit 'n lae-inkomste area van haar dorp, wat die ouma van 'n 2-jarige seun is wat by haar aan huis woon; die dogter van hierdie verpleegster wat ook in dieselfde huis woon en die ma van die 2-jarige kleinseun is; en 'n verpleegsuster, ook die ouma van 'n 2-jarige seun wat tot kort vóór die fokusgroepbespreking by haar woonagtig was. 'n Tweede fokusgroep is in Stellenbosch gehou met twee educare-werkers (beide woonagtig op plase buite die Stellenbosse dorpskern, waarvan een die ma van 'n 1-jarige seun en drie ouer kinders was); 'n 
huisdokter wat onlangs van Pretoria na Stellenbosch verhuis het (die ma van 'n aangenome 2jarige dogter en vier ouer kinders); twee laerskoolonderwyseresse, een vir die grondslagfase (met 'n dogter van 1 jaar en 'n seun van 3, woonagtig in die noordelike voorstede van Kaapstad) en die ander vir die intersenfase (die ma van 'n 1-jarige seun en 3-jarige dogter, woonagtig in die Strand); en 'n praktiserende spraak-taalterapeut en oudioloog met twee jong laerskoolkinders. Sommige deelnemers was dus ouers of grootouers van jong kinders wat in Afrikaans grootgemaak word, ander deelnemers het in hul professionele hoedanigheid met jong Afrikaanssprekende kinders gewerk, en vir sommige deelnemers was beide die geval. Die doel van die fokusgroepbesprekings was om vas te stel watter woorde volgens die informante tot die lys toegevoeg moes word en vir watter bestaande woorde daar alternatiewe vorme gelys moes word. (Soos later aangetoon sal word, kan nie alle aanbevelings van die fokusgroepe egter sonder meer geïmplementeer word nie.) Ons het ook spraakvoorbeelde van ses Afrikaanssprekende kinders van 29 tot 36 maande versamel en ons het die Stellenbosch-korpus op CHILDES (spesifiek Jean en Chanel se uitinge van 18 tot 35 maande; Van Dulm, geen datum) geraadpleeg om te verseker dat ons voorlopige lys woorde daardie woorde insluit wat in die spraakvoorbeelde en korpus voorkom. Die voorlopige lys is ná die byvoeging en verwydering van items (op grond van die bydraes gelewer deur die gekonsulteerde taalwetenskaplikes en spraak-taalterapeute, fokusgroeplede, spraakvoorbeelde en CHILDES-korpus) deur 90 ouers van Afrikaanssprekende 8- tot 30-maand-oue kinders uit beide stedelike en landelike gebiede voltooi (tydens Loodsstudie 1) om data te lewer op grond waarvan ons kon besluit watter gebare, woorde en kort sinne van die lys verwyder moet word. Die verkorte lys sal deur 200 ouers van Afrikaanssprekende kinders van 8 tot 30 maande voltooi word (tydens Loodsstudie 2) waarna die finale aanpassings gemaak sal word voordat die geldigheid van die lys geverifieer word.

Oorwegings tydens die opstel van 'n ouervraelys oor vroeë kindertaalverwerwing sluit die volgende in: Alhoewel dit gewoonlik die maklikste, vinnigste en goedkoopste vir navorsers is om slegs middelklas ouers in stedelike gebiede te raadpleeg oor die woorde wat hul kinders ken, kan dit lei tot diskriminasie teen kinders wat minderbevoorreg is, wat in plattelandse gebiede woon, wat 'n niegestandaardiseerde variëteit van hul taal praat, wie se ouers nie hoë geletterdheidsvlakke het nie en/of wat nie deel is van die hoofstroom- of dominante kultuur nie. Taaltoetse diskrimineer gereeld teen hierdie kinders (vgl. bv. Campbell, Dollaghan, Needleman en Janosky 1997), en toon dan foutiewelik aan dat die kinders 'n taalagterstand of taalgestremdheid het selfs as hulle goed ontwikkel volgens die norme van hul gemeenskap. Om hierdie situasie te vermy win ons ook data in uit armer en plattelandse gebiede en onder ouers en professionele kindertaalwerkers wat bekend is met 'n niegestandaardiseerde variëteit van Afrikaans. Soos hierbo verduidelik, word die uitgebreide voorlopige lys aan groter groepe ouers van jong Afrikaanssprekende kinders gegee om in te vul om sodoende wyer terugvoer te verkry voordat ons die vraelys finaliseer en nasionale norme daarvoor opstel. Alhoewel ons ons lys volledig en verteenwoordigend wil kry, moet ons die einddoel van die lys in gedagte hou: Dit moet deur ouers ingevul word om inligting te verskaf oor hul jong kinders se taalontwikkeling, vir kliniese of navorsingsdoeleindes. Om hierdie rede moet die lengte van die lys beperk word: Ouers kan ontmoedig word as hulle oormatig lang lyste woorde moet deurgaan waarvan hul kind dalk min ken, veral ouers van baie jong kinders, wat veronderstel is om nog min woorde te ken. Verder moet die woorde wat op die lys ingesluit word, 'n ontwikkelingsverloop toon: Die waarskynlikheid dat 'n kind 'n woord ken, moet toeneem namate die kind se ouderdom toeneem. Ingeslote woorde moet dus nie skielik, op grond van blootstelling aan 'n sekere konsep, in net sommige kinders se woordeskat verskyn nie. Tuimeldroër kan byvoorbeeld op 
die lys ingesluit word as die woord nie aan jonger kinders bekend is nie maar wel aan ouer kinders, maar nie as dit blyk dat slegs kinders wat tuimeldroërs in hul huise het, die woord tuimeldroër ken nie.

Die vraag ontstaan dus watter woorde op die lys ingesluit moet word en watter weggelaat moet word. Ons het ons in hierdie verband laat lei deur die terugvoer van die fokusgroepe, maar daar was steeds finale oordele wat deur ons gevel moes word, en ons moes, soos hierbo genoem, in gedagte hou dat die lys nie onbeperk uitgebrei kan word nie, want dan mag ons onbetroubare data verkry vanaf ouers wat die lys voltooi. Hieronder deel ons van die besluite wat deur ons geneem moes word oor die insluiting en uitsluiting van woorde.

Daar blyk groot geografiese verskille te wees in die woorde wat jong Afrikaanssprekendes verwerf. Die Noord-Kaapse fokusgroep het byvoorbeeld aangedui dat skerpioen op die lys vroeg-ontwikkelende dierename ontbreek. In daardie streek is skerpioen om veiligheidsredes 'n woord wat kinders van kleins af moet ken. In die Boland-streek van Wes-Kaap blyk skerpioen egter nie vroeg-ontwikkelend te wees volgens die fokusgroeplede uit daardie streek nie. Gegee die klein bevolking van die Afrikaans-dominante Noord-Kaap Provinsie (vgl. Statistics South Africa 2012) moes ons besluit of dit wel nodig is om hierdie ekstra woord tot die reeds lang lys dierename op die lys toe te voeg. Omdat ons armer en plattelandse kinders wil bevoordeel bo meer gegoede stedelinge (in gevalle waar bevoordeling van enige aard nie vermy kan word nie), kon ons nie hierdie bydrae uit die Noord-Kaap sonder meer ignoreer nie. Ons het besluit om dit vir eers op die lys in te voeg, maar het dit later verwyder nadat Loodsstudie 1 aangedui het dat skerpioen nie algemeen vroeg verwerf word nie. 'n Makliker bydrae om te ignoreer - ook 'n dierenaam - was dat dolfyn volgens een lid van die Stellenbosse fokusgroep tot die lys toegevoeg moet word. Dolfyn is waarskynlik meer bekend aan kinders in kusstreke en diegene wat al die geleentheid gehad het om 'n dolfyn teë te kom (in die see, 'n akwarium of kinderboeke) en is dus weggelaat omdat sy insluiting teen kinders in landelike gebiede kon diskrimineer. Om soortgelyke redes sou koeskoes, takbok en universiteit wat in die datastel van Brink (2018) voorkom, nie op die voorlopige lys verskyn nie.

Daar is sommige woorde wat slegs deur sekere etniese groepe voorgestel is as vroegontwikkelend in die Afrikaans van kinders in hul gemeenskap. 'n Voorbeeld hiervan is dat krullers en lyfsproei belangrik blyk te wees onder jong Bruin sprekers van Afrikaans (volgens lede van beide fokusgroepe) en onderskeidelik na verwys word as curlers en spray. Hierdie items is deur geen Wit fokusgroepdeelnemer as belangrik genoem nie, maar dit kan wees omdat daar nie verteenwoordiging van Wit deelnemers met laer sosio-ekonomiese status in die fokusgroepe was nie en die meeste Bruin deelnemers aan die fokusgroepe wel lae sosioekonomiese agtergronde gehad het. Om seker te maak dat ons nie teen voorheen uitgeslote groepe diskrimineer nie, het ons besluit om woorde soos curlers en spray in te sluit op ons lys van vroeg-ontwikkelende woorde in die taal van eentalige Afrikaanssprekende kinders, saam met hul Standaardafrikaanse ekwivalente.

Sommige woorde om tot die lys toe te voeg is verder slegs deur diegene met hoër sosioekonomiese status voorgestel. Avokadopeer was so 'n woord. Gegee die verkoopprys van avokadopere, is dit onwaarskynlik dat kinders jonger as 3 jaar uit lae inkomstegroepe buite avokadopeer-produserende gebiede (hoofsaaklik Limpopo en Mpumalanga en tot 'n veel kleiner mate dele van KwaZulu-Natal; vgl. Department of Agriculture, Forestry and Fisheries 2012:2) wyd bekend sal wees met avokadopere en dus met die woord avokadopeer. 
Avokadopeer is dus ' $n$ woord wat weggelaat is op die lys wat aan die groter groepe ouers gegee is vir proefvoltooiing.

Ons bespreek nou die uitdagings wat spesifiek te make het met taalvariasie, verskynsels wat ons nie genoop het om te besluit of daar 'n woord vir 'n referent ingesluit of weggelaat moes word nie, maar eerder watter woord/e vir 'n referent ingesluit moes word. Sommige van hierdie variasie kan wel aan geografiese, etniese of sosio-ekonomiese faktore toegeskryf word, maar ander nie.

Die eerste soort uitdaging wat ons teëgekom het, is dat Variëteite 1 en 2 beide 'n sekere woord gebruik, maar dat die woord twee verskillende betekenisse in die twee variëteite het. Koe(k)si(e)ste(r) is hier 'n voorbeeld. Alhoewel hierdie woord in beide Kaaps en Standaardafrikaans na 'n soet lekkerny verwys, is die referent van koeksister in Standaardafrikaans brosgebraaide stukkies saamgevlegte deeg wat in suikerstroop gedoop is terwyl koesieste in Kaaps verwys na 'n groter, langwerpige, sagte oliegebraaide stuk deeg wat in klapper gerol is. Die Standaardafrikaanssprekende fokusgroepdeelnemers wou graag koeksister op die ouervraelys sien, en die Kaapssprekendes was van mening dat koesieste op die lys moet verskyn. Ons het besluit dat aangesien die twee klankvorme beide na soet, oliegebraaide lekkernye verwys, ons hulle as één item sal aanbied op die voorlopige vraelys: koesieste / koeksister.

'n Tweede uitdaging is dat een woord dieselfde referent in Variëteit 1 en 2 het, maar Variëteit 1 'n sinoniem vir daardie woord het wat nie noodwendig as 'n sinoniem vir die woord in Variëteit 2 dien nie. 'n Voorbeeld hiervan is doek, waarvan die referent in Kaaps 'n kopdoek, babadoek, tafeldoek of groot stuk materiaal is (lg. waarmee kos of 'n gedekte tafel bedek word), maar in Standaardafrikaans is die referent gewoonlik 'n babadoek (vgl. ook hieronder). Mammie is ook hier 'n voorbeeld: Die referent van mammie is 'n ma of ouma in Kaaps (of enige ouer dame as die spreker bv. 'n taxibestuurder is), maar slegs 'n ma in Standaardafrikaans. 'n Derde voorbeeld is die stel doek, nappy en kimby. In Kaaps word laasgenoemde twee naas doek gebruik om na 'n babadoek (spesifiek 'n weggooidoek) te verwys terwyl doek (en minder gereeld nappy) in Standaardafrikaans gebruik word, maar nie kimby nie. Hierdie probleem is oorkom deur alle sinonieme langs mekaar te lys, al sou kimby 'n onbekende woord vir die meeste sprekers van Standaardafrikaans wees.

'n Verwante, meer komplekse uitdaging kom voor wanneer 'n bepaalde referent met Woord A benoem word in Variëteit 1 maar met Woord B in Variëteit 2. Woord B bestaan wel in Variëteit 1, maar is nie 'n sinoniem vir Woord A nie, en Woord A kom nie algemeen in Variëteit 2 voor nie. Een voorbeeld hiervan is die referent bobene wat met bobene in Standaardafrikaans benoem word maar met boude of pale in Kaaps. Boude en pale kom natuurlik wel in Standaardafrikaans voor, maar het nie dieselfde referente as in Kaaps nie, aangesien Standaardafrikaanse boude se referent agterstewe is. Verder is bobene 'n woord wat deur min sprekers van Kaaps gebruik sal word en dus 'n onwaarskynlike vroeg-ontwikkelende woord onder Kaapssprekende kinders sal wees. Pale verwys in Standaardafrikaans na lang dun boumateriaal wat gewoonlik uit hout of metaal gemaak is, en nie na bobene nie. Daar is dus hier in twee gevalle één referent met twee potensieel verwarrende klankvorme: Kaapssprekendes kan wanneer die woorde vir bobene as bobene / boude / pale op die vraelys aangebied word, bobene ignoreer en aandui dat hul kind die woord vir boonste deel van die bene (boude of pale) ken, maar sprekers van Standaardafrikaans mag dink dat hulle in een en dieselfde item op die vraelys gevra word of 
hul kind die woord vir die boonste deel van die bene of agterstewe of boumateriaal ken. Daar was geen teoretiese of ander basis waarop ons kon besluit watter variëteit se woord(e) vir bobene bo die ander gekies moes word nie; ons het dus diskresie aan die dag gelê en boude en bobene (maar nie die meer informele pale nie) op die voorlopige lys ingesluit.

Rakende boude kan daar verder genoem word dat woorde vir beide die referent bobene en boude op ouervraelyste in vele ander tale voorkom. Dit is dus baie moontlik dat woorde vir beide bobene en boude op die Afrikaanse vraelys ingesluit sal moet word. Een Kaapse sinoniem vir boude - naas sterre, bakke en bums - is egter holle, wat 'n plat woord in Standaardafrikaans is, en 'n besluit moet geneem word oor die insluiting van plat woorde (wat aanstoot kan gee) in die ouervraelys: Ons moes besluit of ons op skrif vir ouers gaan vra of hul kinders die woord holle ken (want gegee bostaande bespreking sal ons dan vra oor bobene/boude en boude/holle, met boude wat dan (moontlik) verwarrenderwyse twee maal in die semantiese klas "menslike liggaamsdele" voorkom en na twee verskillende liggaamsdele verwys). Dieselfde probleem doen hom voor met die woord wat na borste verwys. Omdat die vraelys vir moontlik steeds borsmelkdrinkende kinders (onder 3 jaar) bedoel is, is dit 'n woord wat moontlik tersaaklik vir die ouervraelys is. Die Kaapse woord tet - wat blyk die mees algemeen gebruikte klankvorm vir hierdie referent onder jong Kaapssprekende kinders en Bruin sprekers van Afrikaans in die Noord-Kaap te wees, op grond van die inligting wat ons konsultante en fokusgroeplede verskaf het - word egter as plat beskou deur sprekers van Standaardafrikaans, wat bors, tietie of 'n gesin-spesifieke term verkies. (En in Kaaps kan tietie verwys na 'n ouer vrou soos 'n ma of 'n ouma.) Hier het ons besluit om nie woorde in te sluit wat plat is in een variëteit maar die mees algemene woord vir 'n alledaagse referent is in 'n ander variëteit nie; ons het eerder "die woord wat julle daarvoor gebruik" ná die ander woord(e) ingevoeg, byvoorbeeld bors / tietie / die woord wat julle daarvoor gebruik.

Die vyfde uitdaging het met sleng te make. In sommige gevalle is die enigste aanvaarbare woord vir 'n sekere referent in Variëteit 1 'n slengwoord in Variëteit 2. Beskou die woorde wat gebruik word om na 'n fiets te verwys: In Standaardafrikaans sal dit fiets wees, maar in Kaaps is dit bicycle of bike, maar nie fiets nie. Dieselfde geld vir mikrogolfoond wat in Standaardafrikaans mikrogolf en mikro as wisselvorme het, maar nie microwave of micro nie. Micro(wave) is egter die ongemarkeerde Kaaps vir 'n mikrogolfoond. Ons het besluit dat wanneer ons wil vasstel of 'n kind 'n woord vir die referent mikrogolfoond het, ons die lys van moontlikhede gaan verskaf (mikrogolfoond / mikrogolf / mikro / microwave / micro) - en dieselfde geld vir soortgelyke gevalle soos gordel / belt - met nie-leenwoorde wat telkens die leenwoorde voorafgaan.

Die laaste uitdaging wat ons moet hanteer, is die hoë voorkoms van verkleinwoorde in die Afrikaans wat aan kinders gerig word. Aangesien verkleinwoorde algemeen in kindgerigte taal gebruik word, is hulle vermoedelik ook algemeen in kinders se vroeë gesproke woordeskat. Die vraag het ontstaan of ons om hierdie rede die naamwoorde op die ouervraelys ook as verkleinwoorde moet aanbied (bv. kat / katjie, woef / woefie, melk / melkies, neus / neusie, slaap / slapies). Indien wel, sou dit die aantal items wat deur ouers oorweeg moet word terwyl hulle die vraelys voltooi, aansienlik verhoog, wat (soos hierbo verduidelik) onwenslik is. Om hierdie rede het ons besluit om verkleinwoorde sover moontlik in die ouervraelys te vermy. 


\section{Slotopmerkings}

Om te bepaal watter woorde op 'n ouervraelys oor kindertaalontwikkeling ingesluit moet word, is nie ' $n$ onbenullige saak nie. Bestaande taaltoetsinstrumente diskrimineer gereeld grootliks teen kinders wat nie deel van die dominante kultuur en taalgemeenskap is nie. In die Verenigde State van Amerika is daar byvoorbeeld meer Afro-Amerikaanse as Wit Amerikaanse kinders in opvoedkundige programme vir kinders met spesiale leerbehoeftes (Skiba, Poloni-Staudinger, Gallini, Simmons en Feggins-Azziz 2006), en hierdie oorverteenwoordiging van AfroAmerikaners word minstens gedeeltelik toegeskryf aan oordiagnose met ontoepaslike toetsinstrumente (vgl. Craig 1996). In Suid-Afrika met haar bevlekte geskiedenis wat die erkenning van persone van kleur en sprekers van niegestandaardiseerde taalvariëteite betref (vgl. bv. Hendricks 2012; vgl. ook Williams 2016 vir 'n perspektief op hedendaagse Kaaps), is die opstel van 'n regverdige en geldige ouervraelys ononderhandelbaar. Ons moet dus noukeurig oorweeg watter woorde op die lys ingesluit word.

'n Goeie ouervraelys sal bydra tot kultureel en talig regverdige taaltoetsing van jong Afrikaanssprekende kinders. Dit sal help om kinders te identifiseer wat sukkel om hul taal te verwerf en wat ekstra hulp benodig sodat hul taal genoegsaam kan verbeter vóór hul formele skoolloopbaan 'n aanvang neem. Sodoende sal hulle 'n groter kans hê om die kurrikulum te verstaan, skoolsukses te ervaar en lank genoeg op skool te bly om hul potensiaal te verwesenlik. Benewens hierdie praktiese en opvoedkundige voordeel vir kinders sal 'n goeie ouervraelys ook grootskaalse navorsing oor vroeë kindertaalverwerwing in Afrikaans moontlik maak. Omdat ons nog bykans geen inligting het oor hoe Afrikaanssprekende kinders taal verwerf nie, kan ons ook nie data-gebaseerde opleidingskursusse oor hierdie onderwerp ontwikkel nie (bv. vir diensverskaffers en opvoeders in die vroeë kinderontwikkelingsektor); ons word genoop om inligting te gebruik wat grootliks gebaseer is op kinders wat in noordelike wêrelddele grootword en wie se tale nie altyd aan Afrikaans verwant is nie. Ons berei dus nie tans ons studente optimaal voor vir die werklikhede wat hulle gaan teëkom wanneer hulle hul beroepe in vroeë kinderontwikkeling betree nie. Meer navorsing oor plaaslike kindertaalontwikkeling sal help om hierdie situasie te verbeter.

In hierdie artikel het ons aangetoon dat Afrikaanse taalvariasie uitdagings aan regverdige kindertaaltoetsing stel. Statistiese ontledings van groot hoeveelhede ouerverskafte data sal ons finale besluite oor die insluiting of uitsluiting van woorde lei, maar statistiese verwerkings kan nie in alle gevalle insluiting teenoor uitsluiting dikteer nie. Ons het onsself verbind tot die opstel van 'n ouervraelys oor kindertaalverwerwing wat van praktiese en akademiese nut is en wat regverdig is teenoor sprekers van alle Afrikaanse taalgemeenskappe, en daarom gaan ons voort om op 'n konsulterende wyse uitdagings oor die inhoud van die ouervraelys te hanteer.

\section{Erkennings}

Die navorsing waarop hierdie artikel gebaseer is, vorm deel van die aktiwiteite van die SuiderAfrikaanse Communicative Developmental Inventory-span, wat befonds is deur (i) 'n SADiLaR-toekenning aan Heather Brookes, (ii) 'n toekenning van die Nasionale Navorsingstigting van Suid-Afrika (Menslike en Sosiale Dinamika HSD170602236563) aan Frenette Southwood, (iii) ' $\mathrm{n}$ toekenning van die Nasionale Navorsingstigting van SuidAfrika/Sweedse Stigting vir Internasionale Samewerking in Navorsing en Hoër Onderwys (NRF/STINT160918188417) aan Michelle Pascoe en andere, en (iv) 'n toekenning van die 
Britse Akademie Newtonfonds (NG160093) aan Katie Alcock (Lancaster Universiteit) en Heather Brookes.

\section{Verwysings}

Alcock, K., K. Rimba, P. Holding, P. Kitsao-Wekulo, A. Abubakar and C.R.J.C Newton. 2015. Developmental inventories using illiterate parents as informants: Communicative Development Inventory (CDI) adaptation for two Kenyan languages. Journal of Child Language 42: 763785. https://doi.org/10.1017/s0305000914000403

Alcock, K.J., A. Ali, C.R. Newton and P. Holding. 2016. The effects of prenatal HIV exposure on language functioning in Kenyan children. BMC Research Notes 9: 463-468. https://doi:10.1186/s13104-016-2264-3

Au, T.K.F., M. Dapretto and Y.K. Song. 1994. Input vs constraints: Early word acquisition in Korean and English. Journal of Memory and Language 33(5): 567-582. https://doi.org/10.1006/jmla.1994.1027

Barwick M.A., N.J. Cohen and N.B. Horodezky. 2004. Infant commmunication and the motherinfant relationship: The importance of level of risk and construct measurement. Infant Mental Health Journal 25(3): 240-266. http://doi.org/10.1002/imhj.20000

Beitchman J.H., H. Jiang, E. Koyama, C.J. Johnson, M. Escobar, L. Atkinson, E.B. Brownlie and R. Vida. 2008. Models and determinants of vocabulary growth from kindergarten to adulthood. Journal of Child Psychology and Psychiatry 49(6): 626-634. http://doi.org/10.1111/j.1469-7610.2008.01878.x

Bleses, D., W. Vach, M. Slott, S. Wehberg, P. Thomsen, T.O. Madsen and H. Basbøl. 2008. Early vocabulary development in Danish and other languages: A CDI-based comparison. Journal of Child Language 35(3): 619-650. https://doi.org/10.1017/s0305000908008714

Broomfield, J. and B. Dodd. 2004. Children with speech and language disability: Caseload characteristics. International Journal of Language and Communication Disorders 39(3): 303324. http://doi.org/10.1080/13682820310001625589

Bornman, J., M. Romski, K. Tonsing, R. Sevcik, R. White and A. Barton-Hulsey. 2018. Adapting and translating the Mullen Scales of Early Learning for the South African context. South African Journal of Communication Disorders 65(1). https://doi.org/10.4102/sajcd. $\underline{\mathrm{v} 65 \mathrm{i} 1.571}$

Bornstein, M.H., L.R. Cote, S. Maital, K. Painter, S.Y. Park, L. Pascual, M-G. Pecheux, J. Ruel, P. Venuti and A. Vyt. 2004. Cross-linguistic analysis of vocabulary in young children: Spanish, Dutch, French, Hebrew, Italian, Korean, and American English. Child Development 75(4): 1115-1139. https://doi.org/10.1111/j.1467-8624.2004.00729.x

Brink, N. 2018. Afrikaans speaking children's first lexical items. Available online: https://hdl.handle.net/20.500.12185/479 
Brink, N. en Breed, A. 2017. Hoe jong Afrikaanssprekende kinders betekenis aan hul vroeë taalgebruik verbind. Tydskrif vir Geesteswetenskappe 57(4): 1012-1036. http://doi.org/ $\underline{10.17159 / 2224-7912 / 2017 / \mathrm{v} 57 \mathrm{n} 4 \mathrm{a} 10}$

Buitendag, M., I.C. Uys en B. Louw. 1998. Afrikaanse reseptiewe woordeskattoets (ARW): Toepaslikheid vir 'n groep nie-standaardafrikaanssprekende kinders. Suid-Afrikaanse Tydskrif vir Kommunikasieafwykings 45(1): 11-29. https://doi.org/10.4102/sajcd.v45i1.715

Campbell, T, C. Dollaghan, H. Needleman and J. Janosky. 1997. Reducing bias in language assessment: Processing-dependent measures. Journal of Speech, Language, and Hearing Research 40(3): 519-525. https://doi.org/10.1044/jslhr.4003.519

Caselli, M.C., E. Bates, P. Casadio, J. Fenson, L. Fenson, L. Sander and J. Weir. 1995. A crosslinguistic study of early lexical development. Cognitive Development 10: 159-199. https://doi.org/10.1016/0885-2014(95)90008-x

Catts, H.W., M.E. Fey, J.B. Tomblin and X. Zhang. 2002. A longitudinal investigation of reading outcomes in children with language impairments. Journal of Speech, Language, and Hearing Research 45: 1142-1157. https://doi.org/10.1044/1092-4388(2002/093)

Conti-Ramsden, G., K. Durkin, P.L.H. Mok, U. Toseeb and N. Botting. 2016. Health, employment and relationships: Correlates of personal wellbeing in young adults with and without a history of childhood language impairment. Social Science \& Medicine 160: 20-28. https://doi.org/10.1016/j.socscimed.2016.05.014

Craig, H.K. 1996. The challenges of conducting language research with African American children. In A.G. Kamhi, K.E. Pollock and J.L. Harris (eds.) Communication development and disorders in African American children: Research, assessment, and intervention. Baltimore: Paul H. Brookes.

Dale, P., E. Bates, J. Reznick and C. Morisset. 1989. The validity of a parent report instrument of child language at twenty months. Journal of Child Language 16: 239-249. https://doi.org/10.1017/s0305000900010394

Dale, P.S. and M. Penfold. 2011. Adaptations of the MacArthur-Bates CDI into non-U.S. English languages. Available online: https://mb-cdi.stanford.edu/documents/Adaptations Survey2011.pdf (Accessed 12 October 2018).

De Boysson-Bardies, B. and M.M. Vihman. 1991. Adaptation to language: Evidence from babbling and first words in four languages. Language 67(2): 297-319. https://doi.org/10.2307/415108

Department of Agriculture, Forestry and Fisheries. 2012. Production guideline - Avocado Persea Americana. Pretoria: The Department of Agriculture, Forestry and Fisheries.

Dickinson, D.K., J.A. Griffith, R.M. Golinkoff and K. Hirsh-Pasek. 2012. How reading books fosters language development around the world. Child Development Research. http://doi.org/10.1155/2012/602807 
Dowling, T. and E. Whitelaw. 2018. Working towards culturally and linguistically diverse speech assessments for South African children: A Xhosa case study. Language Matters 49(2): 39-61. https://doi.org/10.1080/10228195.2018.1467479

Duke, L. 2017. Testing vocabulary size in children under two: Exploring parental reporting through multiple case studies. Unpublished honours research report, Stellenbosch University.

Egan, S.K. and D.G. Perry. 1998. Does low self-regard invite victimization? Developmental Psychology 34(2): 299-309. https://doi.org/10.1037/0012-1649.34.2.299

Fenson, L., P.S. Dale, J.S. Reznick, E. Bates, D.J. Thal, S.J. Pethick, M. Tomasello, C.B. Mervis and J. Stiles. 1994. Variability in early communicative development. Monographs of the Society for Research in Child Development 59(5): 1-185. https://doi.org/10.2307/1166093

Fenson, L., P.S. Dale, J.S. Reznick, D. Thal, E. Bates, J.P. Hartung, S. Pethick and J.S. Reilly. 1993. The MacArthur Communicative Development Inventories: User's guide and technical manual. Baltimore: Paul H. Brokes Publishing Co.

Fenson, L., V.A. Marchman, D.J. Thal, P.S. Dale, J.S. Reznick and E. Bates. 2007. MacArthurBates Communicative Development Inventories. User's guide and technical manual. Second edition. Baltimore: Paul H. Brookes.

Fernald, A. and H. Morikawa. 1993. Common themes and cultural variations in Japanese and American mothers' speech to infants. Child Development 64: 637-656. https://doi.org/10.2307/1131208

Gagarina, N., D. Klop, S. Kunnari, K. Tantele, T. Välimaa, I. Balčiūnienė, U. Bohnacker and J. Walters. 2012. LITMUS-MAIN: Multilingual assessment instrument for narratives. ZAS Papers in Linguistics 56: 1-135.

Gomez, R. 2002. Variability and detection of invariant structure. Psychological Science 13: $431-436$.

Gonasillan, A., J. Bornman and M. Harty. 2013. Vocabulary used by ethno-linguistically diverse South African toddlers: A parent report using the Language Development Survey. South African Journal of Communication Disorders 60: 10-15. https://doi.org/10.4102/sajcd.v60i1.4

Gopnik, A., S. Choi and T. Baumberger. 1996. Cross-linguistic differences in early semantic and cognitive development. Cognitive Development 11(2): 197-227. https://doi.org/10.1016/s0885-2014(96)90003-9

Groenewald, H., A. Kritzinger and M. Viviers. 2013. Age-specific communication functioning of young children with cleft lip and palate in a South African database. Cleft PalateCraniofacial Journal 50(6): 717-729. http://doi.org/10.1597/12-146

Hamadani, J.D., H. Baker-Henningham, F. Tofail, F. Mehrin, S.N. Huda and S.M. GranthamMcGregor. 2010. Validity and reliability of mothers' reports of language development in 1- 
year-old children in a large-scale survey in Bangladesh. Food and Nutrition Bulletin 31: S198S206. https://doi.org/10.1177/15648265100312s212

Haman, E., M. Łuniewska, P. Hansen, H.G. Simonsen, S. Chiat, J. Bjekić, A. Blažienė, K. Chyl, I. Dabašinskienè, P. Engel de Abreu, N. Gagarina, A. Gavarró, G. Håkansson, E. Harel, E. Holm, S. Kapalková, S. Kunnari, C. Levorato, J. Lindgren, K. Mieszkowska, L. Montes Salarich, A. Potgieter, I. Ribu, N. Ringblom, T. Rinker, M. Roch, D. Slančová, F. Southwood, R. Tedeschi, A. Müge Tuncer, Ö. Ünal-Logacev, J. Vuksanović and S. Armon-Lotem. 2017. Noun and verb knowledge in monolingual preschool children across 17 languages: Data from cross-linguistic lexical tasks (LITMUS-CLT). Clinical Linguistics \& Phonetics 31(11-12): 818-843. https://doi.org/10.1080/02699206.2017.1308553

Harrison L.J. and S. McLeod. 2010. Risk and protective factors associated with speech and language impairment in a nationally representative sample of 4- to 5-year-old children. Journal of Speech, Language, and Hearing Research 53(2): 508-529. http://doi.org/10.1044/1092$\underline{4388(2009 / 08-0086}$

Hattam, M., B. Louw and S. Geertsema. 2014. Communication characteristics of young children with HIV in South Africa as reported by some physicians. African Journal of AIDS Research 13(4): 371-382. https://doi.org/10.2989/16085906.2014.985236

Hendricks, F. 2012. Om die miskende te laat ken: 'n Blik op Adam Small se literêre verrekening van Kaaps. Tydskrif vir Letterkunde 49(1): 95-114. http://doi.org/10.4314/tvl.v49i1.8

Henrich, J., S.J. Heine and A. Norenzayan. 2010. The weirdest people in the world? Behavioral and Brain Sciences 33(2-3): 61-83. https://doi.org/10.1017/s0140525x0999152x

Hoff, E. 2003. The specificity of environmental influence: Socioeconomic status affects early vocabulary development via maternal speech. Child Development/Developing 74(5): 13681378. https://doi.org/10.1111/1467-8624.00612

Jerome, A.C., M. Fujiki, B. Brinton and S.L. James. 2002. Self-esteem in children with specific language impairment. Journal of Speech, Language, and Hearing Research 45: 700-714. https://doi.org/10.1044/1092-4388(2002/056)

Johnson, C.P. and S.M. Myers. 2007. Identification and evaluation of children with autism spectrum disorders. Pediatrics 120: 1183-1215. https://doi.org/10.1542/peds.2007-2361

Klop, D., M. Visser and H. Oosthuizen. 2011. Narratives profiles of typically developing 9 year old bilingual South African children. Paper presented at the Fourth Meeting of COST Action ISO804, 25-27 May 2011, Anadolu University, Turkey.

Law, J., J. Boyle, F. Harris, A. Harkness and C. Nye. 2000. Prevalence and natural history of primary speech and language delay: Findings from a systematic review of the literature. International Journal of Language and Communication Disorders 35(2): 165-188. 
Marrus, N. and L. Hall. 2017. Intellectual disability and language disorder. Child and Adolescent Psychiatric Clinics of North America 26(3): 539-554. https://doi.org/10.1016/ j.chc.2017.03.001

McCormack J., S. McLeod, L. McAllister and L.J. Harrison. 2009. A systematic review of the association between childhood speech impairment and participation across the lifespan. International Journal of Speech-Language Pathology 11: 155-170. https://doi.org/10.1080/17549500802676859

Morgan, J.L., R. Shi and P. Allopenna. 1996. Perceptual bases of rudimentary grammatical categories: Toward a broader conceptualization of bootstrapping. In J.L. Morgan and K. Demuth (eds.) Signal to syntax: Bootstrapping from speech to grammar in early acquisition. Mahwah, New Jersey: Lawrence Erlbaum Associates. https://doi.org/10.4324/9781315806822

Mullen, E.M. 1995. Manual for the Mullen Scales of Early Learning. Cranston, RI: T.O.T.A.L. Child.

Nel, J.H. 2015. The comprehension and production of later developing language constructions by Afrikaans-, English- and isiXhosa-speaking Grade 1 learners. PhD dissertation, Stellenbosch University. http://hdl.handle.net/10019.1/97144

Nippold, M.A. 2016. Later language development: School-age children, adolescents, and young adults. Fourth edition. Austin, Texas: PRO-ED.

Pascoe, M., O. Mahura, H. Brookes, T. Dowling, H. Oosthuizen, F. Southwood, N. Kgolo, R. Letsholo and K. Alcock. 2018. Towards Communicative Development Inventories for Southern African children. Poster presented at the Workshop on Current Issues in Child Bilingual Development, 26-27 July 2018, Sydney, Australia.

Pascoe, M. and M. Smouse. 2012. Masithethe: Speech and language development and difficulties in isiXhosa. South African Medical Journal 102(6): 469-471. https://doi.org/10.7196/samj.5554

Perkins, S.C., E.D. Finegood and J.E. Swain. 2013. Poverty and language development: Roles of parenting and stress. Innovations in Clinical Neuroscience 10(4): 10-19.

Preston, J.L., S.J. Frost, W.E. Mencl, R.K. Fulbright, N. Landi, E. Grigorenko, L. Jacobsen and K.R. Pugh. 2010. Early and late talkers: School-age language, literacy and neurolinguistic differences. Brain 133(8): 2185-2195. https://doi.org/10.1093/brain/awq163

Rannard, A., C. Lyons and S. Gless. 2005. Parent concerns and professional responses: The case of specific language impairment. British Journal of General Practice 55(518): 710-714.

Rescorla, L. 1989. The Language Development Survey: A screening tool for delayed language in toddlers. Journal of Speech and Hearing Disorders 54: 587-599. https://doi.org/10.1044/jshd.5404.587 
Rice, M.L., S.F. Warren and S.K. Betz. 2005. Language symptoms of developmental language disorders: An overview of autism, Down syndrome, fragile X, specific language impairment, and Williams syndrome. Applied Psycholinguistics 26: 7-27. https://doi.org/10.1017/ $\underline{\mathrm{S} 0142716405050034}$

Robertson, S.B. and S. Ellis Weismer. 1999. Effects of treatment on linguistic and social skills in toddlers with delayed language development. Journal of Speech, Language, and Hearing Research 42: 1234-1248. https://doi.org/10.1044/jslhr.4205.1234

Rossetti, L.M. 1990. The Rossetti infant-toddler language scale: A measure of communication and interaction. East Moline: LinguiSystems.

Samuels, A., W. Slemming and S. Balton. 2012. Early childhood intervention in South Africa in relation to the developmental systems model. Infants \& Young Children 25(4): 334-345. http://doi.org/10.1097/IYC.0b013e3182673e12

Seymour, H.N., T.W. Roeper and J. de Villiers (with P.A. de Villiers). 2005. Diagnostic evaluation of language variation. Norm referenced. San Antonio, Texas: Pearson.

Simonsen, H.G, K.E. Kristoffersen, D. Bleses, S. Wehberg and R.N. Jørgensen. 2014. The Norwegian Communicative Development Inventories - reliability, main developmental trends and gender differences. First Language 34: 3-23. https://doi.org/10.1177/0142723713510997

Skiba, R.J., L. Poloni-Staudinger, S. Gallini, A.B. Simmons and R. Feggins-Azziz. 2006. Disparate access: The disproportionality of African American students with disabilities across educational environments. Exceptional Children 72(4): 411-424. https://doi.org/10.1177/ $\underline{001440290607200402}$

Southwood, F., M. Carinus and S. Engelbrecht. 2010. The use of discourse markers by Afrikaans-speaking preschoolers with and without specific language impairment. Stellenbosch Papers in Linguistics PLUS 40: 79-94. https://doi.org/10.5842/40-0-6

Statistics South Africa. 2012. Census 2011: Census in brief. Pretoria: Statistics South Africa. Available online: http://www.statssa.gov.za/census/census_2011/census products/Census 2011_Census_in brief.pdf(Accessed 15 October 2018).

Stoeckel, R.E., R.C. Colligan, W.J. Barbaresi, A.L. Weaver, J.M. Killian and S.K. Katusic. 2013. Early speech-language impairment and risk for written language disorder: A populationbased study. Journal of Developmental \& Behavioral Pediatrics 34(1): 38-44.

Squires, J., and D. Bricker. 2009). Ages \& Stages Questionnaires ${ }^{\circledR}$, Third edition (ASQ $\left.{ }^{\circledR}-3\right)$ : A parent-completed child monitoring system. Baltimore: Paul H. Brookes Publishing Co., Inc. https://doi.org/10.1037/t11523-000

Tardif, T., P. Fletcher, W. Liang, Z. Zhang, N. Kaciroti and V.A. Marchman. 2008. Baby's first 10 words. Developmental Psychology 44(4): 929-938. https://doi.org/10.1037/0012$\underline{1649.44 .4 .929}$ 
Tardif, T., S.A. Gelman and F. Xu. 1999. Putting the "noun bias" in context: A comparison of Mandarin and English. Child Development 70: 620-635. https://doi.org/10.1111/1467$\underline{8624.00045}$

Tomblin, J.B, X. Zhang, P. Buckwalter and H. Catts. The association of reading disability, behavioral disorders and language impairment among second grade children. Journal of Child Psychology and Psychiatry 41: 473-82. https://doi.org/10.1111/1469-7610.00632

Trauner, D., B. Wulfeck, P. Tallal and J. Hesselink. 1995. Neurologic and MRI profiles of language impaired children (Technical Report CND-9513). University of California at San Diego, Center for Research in Language.

United Nations. 2018. Sustainable Development Goals. Available online: http://www.undp.org/content/undp/en/home/sustainable-development-goals.html (Accessed 11 October 2018).

Van der Linde, J., D.W. Swanepoel, J. Sommerville, F. Glascoe, B. Vinck and E.M. Louw. 2016. Prevalence and nature of communication delays in a South African primary healthcare context. South African Journal of Child Health 10(1): 87-91. https://doi.org/10.7196/sajch.2016.v10i1.1121

Van der Merwe, K.C. 2008. The comparison of figurative language by Afrikaans-speaking children with and without specific language impairment and by child second language speakers of Afrikaans. MA thesis, Stellenbosch University.

Van Dulm, O. (no date). Stellenbosch corpus. Available online: https://childes.talkbank.org/ access/DutchAfrikaans/Stellenbosch.html (Accessed 31 October 2019).

Van Dulm, O. and F. Southwood. 2013. Child language assessment and intervention in multilingual and multicultural South Africa: Findings of a national survey. Stellenbosch Papers in Linguistics 42: 55-76. https://doi.org/10.5774/42-0-147

Vihman, M.M. and S. Kunnari. 2006. The sources of phonological knowledge: A crosslinguistic perspective. Recherches linguistiques de Vincennes 35: 133-164. https://doi.org/10.4000/rlv.1467

Visser, M., M. Nel, C. Bronkhorst, L. Brown, Z. Ezendam, K. Mackenzie, D. van der Merwe and M. Venter. 2016. Childhood disability population-based surveillance: Assessment of the Ages and Stages Questionnaire Third Edition and Washington Group on Disability Statistics/UNICEF module on child functioning in a rural setting in South Africa. African Journal of Disability 5(1): a265. http://dx.doi. org/10.4102/ajod.v5i1.265

Wadman, R., K. Durkin and G. Conti-Ramsden. 2008. Self-esteem, shyness, and sociability in adolescents with specific language impairment (SLI). Journal of Speech, Language, and Hearing Research 51: 938-952. https://doi.org/10.1044/1092-4388(2008/069) 
Ward, S. 1999. An investigation into the effectiveness of an early intervention method for delayed language development in young children. International Journal of Language and Communication Disorders 34(3): 243-264. https://doi.org/10.1080/136828299247405

Waxman, S.R. and J. Lidz. 2006. Early word learning. In D. Kuhn and R.S. Siegler (eds.) Handbook of child psychology. Sixth edition. Volume 2. Hoboken, New Jersey: Wiley.

Williams, Q.E. 2016. AfriKaaps is an act of reclamation. Mail \& Guardian, 15 December 2016. https://mg.co.za/article/2016-12-15-00-afrikaaps-is-an-act-of-reclamation (Accessed 31 October 2018).

Yew, S.G.K. and R. O'Kearney. 2013. Emotional and behavioural outcomes later in childhood and adolescence for children with specific language impairments: Meta-analyses of controlled prospective studies. Journal of Child Psychology and Psychiatry 54: 516-524. https://doi.org/10.1111/jcpp.12009

Young, A.R., J.H. Beitchman, C. Johnson, L. Douglas, L. Atkinson, M. Escobar and B. Wilson. 2002. Young adult academic outcomes in a longitudinal sample of early identified language impaired and control children. Journal of Child Psychology and Psychiatry 43(5): 635-645. https://doi.org/10.1111/1469-7610.00052 